\title{
APPRAISING NEW APPROACHES TO THE FUNDING OF TERTIARY EDUCATION FOR SUSTAINABLE NATIONAL DEVELOPMENT IN NIGERIA
}

BOLATITO, ABDULRAFIU OMOTAYO

Dept of Educational Foundations, Usmanu Danfodivo University, Sokoto, Nigeria

\begin{abstract}
This paper examined the new approaches to the funding of tertiary education for sustainable development in Nigeria. Tertiary institutions are regarded as the single most important industry for the production of high level manpower needed for the transformation of Nigerian economy and therefore deserve better funding. Tertiary institutions include Universities, Polytechnics and Colleges of Education. However, over the years, tertiary educational institutions in Nigeria have been battling with the issue of insufficient funds from its proprietors because of the insignificant percentage allocated to educational sector and this has crippled tertiary institutions in Nigeria and preventing them attaining fullest capacity, to compete with their counterparts across the globe. Low budgetary allocation to education sector, the sudden collapse of global oil market that lead to sharp reduction in government revenue, and coupled with pressure from academic staff bodies like Academic Staff Union of Universities, Academic Staff Union of Polytechnics, and Colleges of Education Academic Staff Union made government to seek for new approaches of financing tertiary education in Nigeria. This paper therefore, argues that funding of tertiary education should not be the responsibility of government alone, since education is an instrument for economic and social development; parents, educational stakeholders, private sector, employees institutions, nongovernmental organization etc have to make differential contributions to meet the cost of higher education. This paper suggested that government should collaborate with private sector, nongovernmental organizations, and International Financial Organizations such as World Bank, International Monetary Fund to fund tertiary education in Nigeria.
\end{abstract}

Keywords: Education, Financing, Tertiary Education, Sustainable Development.

\section{Introduction}

Since the end of colonialism and Nigeria's independence in 1960, the Federal Government of Nigeria has been dependable and major sources of funding higher educational institutions in the country. And this could be attributed to the effort of government to provide standard and quality education for citizens and an attempt to achieve the objectives of providing affordable and accessible education for all. However, the problem of underfunding of higher educational institutions in Nigeria is a consequence of the expansion of the system in response to the growing demand for higher education and the intensifying needs of modern economy, driven by knowledge, without an increase in the corresponding rates of available resources. Udoh, (2008) notes that Nigeria as a developing nation is currently witnessing increased enrolment of students, virtually in all tertiary institutions. This increase in enrolment demands corresponding increase in funding which is not the case in Nigeria. Okebukola (2002) submits that Nigerian governments have not been able to provide the financial resources necessary to maintain educational quality in the midst of enrolment expansion.

The government (Federal, State and Local Governments) in Nigeria being the proprietor has been major source of funding higher educational institutions in the country. However, due to global recession, economic problems and sharp reduction in the price of crude oil which is major source of government revenue; affected funding of higher educational institutions in the country. Currently, higher educational 
institutions in Nigeria are underfunded (Imbrabekhou and Tower, 2001). Inadequate funding from government lead to inadequate provision of school buildings and facilities and thereby created unconducive teaching and learning in our higher educational institutions. This situations put the higher educational institutions management under stress, hence, they are incapacitated in providing essential services. The faceoff between Nigerian governments and academic staff unions such as Academic Staff Union of Universities, Academic Staff Union of Polytechnics, and Colleges of Education Academic Staff Union coupled with economic depression and drop in oil receipts forced government to seek for alternative ways of funding higher educational institutions in Nigeria.

\section{Conceptual Framework}

The paper exhaustively explained the following related concepts for further clarifications

\section{Higher Education}

The concept of higher education has been defined from different dimensions by different scholars. Nwangwu (2006) defined higher education as the education given after secondary education in universities, colleges of education, polytechnics as well as those institutions offering correspondence courses. Similarly, Akintoye (2008) submitted that higher education system in Nigeria is composed of Universities, Polytechnics, Monothechnics, Institute of Technology and Colleges of Education that form part or are affiliated to universities and professional specialization institutions. Olagboye (2004) opined that higher education refers to the Western type of education which is organized after college of Education. National Policy on Education (2004) sees higher education to include universities, colleges of education, polytechnics and monothechnics. Therefore, higher education refers to all organized learning activities at the tertiary level.

\section{Educational Finance}

Okunamiri (2002) described educational financing as a branch of knowledge that deals with important examination of cost versus expenditure in the production of education services. According to Olagboye (2004) educational finance is a means by which money is provided for the development and maintenance of the entire education system. All activities that are geared towards the process of sourcing, allocating and managing public school revenues in the production of educational services for the attainment of educational objectives constitutes educational finance. Akinsanya (2000) sees educational finance as the process of procuring and disbursing of financial resources for the provision of education of a given standard, stipulated by the society.

\section{Sustainable Development}

Sustainable development connotes development that is achieved without compromising future generations. It is the ability to meet the basic needs such as food, shelter, health and protection (Olubiyo, 2011). 


\section{Theoretical Framework}

This paper adopted two theories that further explain the issues of financing higher education in Nigeria. Human Capital Theory and Neoclassical Theory of Firm were explored in the paper to give a theoretical and empirical insight into the issue of higher educational financing. Neoclassical Theory of Firm in its basic form, views the firm as a black box rational entity. The theory is built on imaginary but plausible production and demand functions and it establishes the principle of profit maximization according to which profit is maximized when marginal revenue is equal to marginal cost (Aina, 2002).

The theory may be used to describe among other things, various market structures, regulation issues, strategic pricing and barriers to entry, economics of scale and scope and even optimum portfolio selection of risk asset (Yusuf 2010). The theory of the firm was traditionally one branch of micro economics which studies the supply of goods by profit maximizing agents (Olanrewaju, 2003). In this theory, production cost played a crucial role. The theory has to do with so many economics theories that explain and describe how firm, companies or organization behave in relation to the market structure (Aina, 2002). According to Olanrewaju (2003), Ronald Coarse is said to be the founder of the theory in 1937 . He believed that firm must be consistent with constant returns to scale rather than relying on increasing return to scale. Cease further believed that the size of the firm is dependent on the cost and on the costs of organization of their entrepreneurs. He said that these two factors together determine how many products a firm or organization produces and how much of each is to be produced and at what cost. Theory of the firm is used to estimate the cost of graduate production in Nigerian higher education. It was also utilized to define the difference between the revenue and the cost in absolute form, and this is impossible when total expenditure is divided by the output or number of students in order to get more useful data on unit cost and how the higher education control unnecessary expenses to avoid wastage.

The paper also adopted Human Capital Theory. There is an increasing awareness of the applicability of the theory in the developing countries to address the issue of higher education financing, especially by the international organizations such as UNESCO, World Bank, UNICEF etc. Olagboye (2004) stress that human capital theory deals with private and public rate of returns to education and its impact on higher education investment and funding. Human capital is the stock of competencies, knowledge and social personality attributes including creativity embodied in the ability to perform labor so as to produce economic value (Obasi, 2000). It is widely accepted that education and training raise the productivity of workers by imparting useful knowledge and skills, hence raising workers future income by increasing their life time earnings (Schultz in Ahmed, 2015). Expenditure on education is generally most costly and should be considered an investment since it is undertaken with a view to increasing personal income.

\section{Currents Levels of Public Funding of Higher Education in Nigeria}

Funding of higher education is one of the most critical issues in the contemporary debate in education system. This is because only adequate funding could guarantee satisfactory provision of both material and human resources that are necessary for 
effective operation of the education sub-sector. The Federal Government of Nigeria (2004) recognizes education as expensive social services that require adequate financial provision for the successful implementation of the educational programmes. There is therefore the need to have a sustainable financing framework in place to ensure that higher education remains relevant as a supplier of manpower to all other educational levels and builder of the nation's economy. This, unless urgently addressed, could stifle higher education goal attainment in the long run. The overall public spending on different levels and types of education had been influenced by the federal government expenditure profile. In Nigeria, the situation of increased spending by one level of government will result in a decrease in another. Therefore, the principle of increased allocation to education has far reaching financial implications for other competing social services and ordering of national priorities (National Bureau of Statistics in Akintoye, 2008).

The amount of money Nigerian government devotes to education, which is far lower than the $26 \%$ of government expenditure as recommended by United Nations Educational Scientific and Cultural Organization (UNESCO), illustrates her poor commitment to the development of education and explains in part, the little progress that has been made in the sector since 1990. During the oil crisis in the 80s, the administration and funding of the education system suffered considerably failing to mitigate the effect of lack of adequate finance, other alternative agencies have also participated significantly in funding Nigerian education. The Education Trust Fund (ETF) now Tertiary Education Trust Funds (TETFUND) is one of these funding agencies. The Tertiary Education Trust Fund (TETFUND) is a trust fund established by decree in 1993 (amended by Act of 40 of 1998) with the objective of using fund combined with project management to improve the quality of education in Nigeria. According to the Act, all organizations and companies of identified minimum operating capacity and registered in Nigeria contribute a level of $2 \%$ of their annual assessable profit to the fund. These contributions complement federal and state budgets allocation to education.

\section{Funding of Tertiary Education in Nigeria}

The underlying rationale for public funding of education is to equip people with the requisite knowledge, skills and capacity to enhance the quality of life, augment productivity and capacity to gain knowledge of new techniques for production, so as to be able to participate actively in the development process. In the words of Ekundayo (2008) public sector funding of education in Nigeria is anchored on the notion that for society to continue in perpetuity, the new generation must be given the appropriate access to knowledge that previous generation have accumulated. Initially, University College Ibadan being the only University in the country was adequately funded in all aspects of teaching and research. In fact, the first generation universities were all well-funded and some of them established and maintained internationally acclaimed and respected standards. It was reported that there were years in which the amount received was slightly more than the amount requested, this is no longer true today (Okebukola, 2003). Hincliffe (2002) highlighted that federal budgetary allocation to education in nominal terms rose from $\$ 6.2$ million in 1970 to $\$ 1,051.2$ million in 1976. Thereafter, it declined to $\$ 667.1$ million in 1979 , rose again to $\$ 1,238.5$ million in 1980 , declined in succeeding years before rising to $\$ 3,399.2$ million in 1989. It dropped further to $\$ 1,553.3$ million in 1991 before rising gradually 
to $\$ 9,343.7$ million in 1994. Thereafter, the declining trend continued. Specifically in 1996, the federal government funded its polytechnics at the rate of 251 dollar per student, its Colleges of Education at the rate of 394 dollar per student and its Universities of the rate of 300 dollar per student. However, in the year 2000, funding of tertiary institutions did improve significantly. For the Federal Universities, unit costs rose from 370 dollar to 932, a rise of $252 \%$. Current funding levels are low and leading to poor remuneration for academic staff. Ekundayo (2008) notes that between 1990 and 1999, for instance, as a result of enrolment growth and currency devaluation, recurrent allocation per university student in federal system fell from 610 to 360 dollars and this has obvious implications for education quality. Thus, in current value terms, the governments recurrent grants to federal universities would appear to have increased dramatically, from 530 million naira in 1988 to 9.6 billion naira in 1999. In real terms, however, total recurrent grants per student in 1999 were at only one third of their 1990 level. Thus, increased budgetary allocation has been muted by the effect of rising enrolment.

\section{The Implications of Inadequate Funding of Higher Educational Institutions in Nigeria}

The problem of underfunding which is a major challenge confronting higher educational institutions in Nigeria had adverse effects on their performance. Over the years, tertiary institutions in Nigeria have witnessed a significant growth and expansion of access through increase in enrolment and establishment of additional tertiary institutions by the state and federal governments. However, it is disheartening to note that many of the indices that can guarantee qualitative higher education are not taken into consideration in the country's quest to meet quantitative target. It has been observed that political factors are the main motives behind many of the expansion policies especially in the university system (Ekundayo, 2008). The Nigerian government found it difficult to sufficiently fund its tertiary institutions because of the growing enrollment without a corresponding impressive quality of funding due to economic depression. There is no doubt that tertiary institutions in Nigeria are underfunded as a result of low budgetary allocation to education sector. This could be attributed to the perception by some policy makers that education does not provide immediate Return On Investment (ROI) compared to other sectors. Poor leadership, corruption and mismanagement of resources have also contributed to the gross underfunding of higher education which have adverse effects on both staff and students. Bamiro and Adedeji (2010) indicated that the quality of teaching and research has fallen considerably because of lack of adequate teaching and research materials, coupled with overcrowded, unconducive teaching and learning environment.

In fact, capital projects to meet the expanding programmes could not take off in case where they took off they had to be abandoned due to lack of funds. The result according to Ekundayo (2008) there was a summon table pressure on the available limited resources thereby resulting in downward pressure on staff salaries together with deteriorating working conditions. The effect includes high degree of "brain drain" among the academic staff incessant strike action, students riots and lecture boycott. All these will have adverse effect on the quality of higher education in Nigeria. 
Furthermore, the effects of inadequate funding are evident in the fact that the physical facilities are in deplorable state, several capital and research projects have been abandoned, laboratories and libraries are ill equipped, academic staff do not attend conferences regularly and there is a drastic reduction in the award of research grants and fellowships. Although the National Policy on Education acknowledges the fact that adequate funding is a criterion for the success of any educational programme. Adeniyi (2008) noted that there is a general reduction in efficiency and production of higher educational institutions because of paucity of funds. Yusuf (2010) adds that the facility carrying capacity of the higher educational institutions in Nigeria have dropped drastically and the proportion of quality staff dropped significantly as a result of inadequate funding.

Higher educational institutions in Nigeria need to respond quickly to the financial challenges currently confronting them by developing more creative and adaptable funding strategies to offset the risks of declining education quality, resources use efficiency and learning effectiveness that now confront them (Christiana, 2011). Government at all levels now seeking for possible new approaches of financing higher educational institutions in Nigeria. Financing higher educational institutions in Nigeria of today is a crucial national problem which requires serious attention. The political, social and economic factors, which are currently having negative impact on the world economy, have necessitated the need to diversify the source of revenue other than heavily rely on government. This is because reliance on only one source of revenue can inhibit educational growth (Akinsanya, 2000).

\section{Approaches to Funding Tertiary Institutions in Nigeria}

Cost Sharing Strategy - The cost sharing strategy has been considered as an alternative source of funding higher education in Nigeria. The economic challenges coupled with partial collapsed of oil market rendered government incapacitated to take full responsibility of funding tertiary education in the country. Since the education is meant for development of society, government alone should not be the sole provider of funds to tertiary institutions in the country. There is need to shift financial burden partly to the individual domain from the social domain which is happening worldwide. Cost sharing is the diversification of revenue source from heavy dependence on the government to being shared with parents and students. Ekundayo (2008) opined that if education were treated as an activity of purely personal concerned, then the students and their families would be made to pay the cost of their own education. This was supported by Ahmed (2013) who said that since the government in Nigeria cannot bear the full burden of funding higher education, it should allow the individual to contribute towards funding the system. Manga (2016) argues that in deciding how to distribute the burden of education expenditure in Nigeria, the national objective should be taken into consideration in order to realize the objectives of building a just and egalitarian society and a free and democratic society.

Development of Internal Efficiency Profile: The concept of efficiency in higher education emphasizes resources must be used efficiently in the sense that there must be maximum output realized per unit of resources. It connotes prudence in the use of available resources. As Ogbodo (1995) rightly noted, an internally inefficient school system would require more funds for any given 
level of operation. Thus, one of the usually overlooked ways of sourcing funds for tertiary institutions is to ensure improved efficiency in the utilization of available resources. If this is properly done, it might well be discovered that the higher education system would achieve much more than it is presently doing with the same level of funding

Public Private Partnership: Pubic private partnership is one of the alternative sources of financing higher education as it is suggested by scholars in Nigeria. Since government cannot bear the full responsibility of funding tertiary institutions in the country there is need for collaborative efforts between government and private sector. Large corporate organizations such as Telecommunication Companies, Dangote Group of Companies, Julius Berger etc should be encouraged to contribute to the development of education in Nigeria either in cash or by building classrooms, lecture rooms and supply of educational equipment. Onibiyo (2011) says that the policy and strategy of government need to focus on providing the incentives and enabling environment, generally, for the private sector to finance education. The government would include the provision of appropriate legislative and regulatory framework, as well as the provision of infrastructure and fiscal incentives such as tax breaks. This will go a long way in relieving government of financial burden. Manga (2014) asserts that in most counties around the word, higher education is financed by a combination of public and private sources of funds. This is supported by Akintoye (2008) who remarked that there is need to share the burden of education through the beneficiaries of educational investment. Also, as part of effort of Federal Government to reduce burden of funding higher education in the country, Tertiary Education Fund (TETFUND) was established in which companies operating in Nigeria were made to pay two (2) percent of their annual profits. The funds from TETFUND has been used to provide educational facilities and construction of buildings for conducive teaching and learning, as well as human capital development.

Commercial Ventures: Commercial ventures have also been considered as an alternative source of funding higher education in Nigeria. Tertiary institutions in the Nigeria should venture into commercial activities such as publishing, consultancies, sales and marketing, bookshops among others in order to complement monthly allocation from government. Okebukola (2002) submitted that government alone cannot bear full responsibility of funding tertiary institutions in Nigeria because of the increasing cost of delivery in higher education brought about by a combination of high enrolment pressure, resistance of institutions to adapt more efficient and productive financial management styles. Since government laid emphasis on the internally generated revenue to all tertiary institutions to supplement what the government is providing, there is need for tertiary institutions to venture into lucrative business that fetch more funds that will enable them to carry out their activities.

International Organizations: The international organizations can serve as alternative source of funding tertiary institutions in Nigeria. The international bodies such as UNESCO, World Bank, United Nations International Children Educational Funds (UNICEF), Canadian International Development Agency (CIDA),United States Agency for International Development (USAID), United Nations Development Programmes (UNDP), etc. Also, Nigerian 
government can seek financial assistance through bilateral agreement with wealthy nations such as United States, United Kingdom, China, Saudi Arabia, Germany, and France etc to finance educational institutions in Nigeria.

Donation and Endowment Funds: Wealthy philanthropic individuals in the communities should provide regular financial assistance for sustainable educational development. In Nigeria, there are so many wealthy individuals who are products of Nigerian higher education. They can be persuaded and encouraged to extend their philanthropic gesture to the development of our higher education. The Late Chief M.K.O. Abiola of blessed memory used to donate funds to all tertiary institutions when he was alive (Ekundayo,2008). Therefore, there is need for government to persuade and encourage private individuals who have benefited from government to contribute to the financial development of Nigerian higher education. Bamiro and Adedeji (2010) said that gifts and donations from the private sector are usually in the form of cash and physical structures given to the tertiary institutions by individuals or groups. Also, the endowment funds have over years been alternative sources of funding higher educational institutions. The authorities of higher educational institutions launch endowment funds by inviting wealthy individuals, corporate organizations, commercial banks and industrial firms, contribute money to help increase revenue base of tertiary institutions.

\section{Challenges/Problems of Funding Tertiary Institutions in Nigeria}

Inadequate allocation of annual budget to the education sector: The tertiary education in Nigeria is facing a heavy expansion and this will continue increasing under the combined effect of population growth and the demand for higher education. Educational expansion should be accompanied with an increased funding. Unfortunately, tertiary institutions in Nigeria many for years now are underfunded. This is due to inadequate allocation of annual budget to the education sector. The budgetary allocation has been on the declined in 1999, 11.2 percent of the annual budget was allocated to education and this reduced drastically to $5.9 \%$ in 2002 and 1.83 percent in 2003 rather than a progressive movement toward the prescribed minimum standard of $26 \%$ by UNESCO, that every developing country of the world should allocate to education annually. On the other hand, the experience is a systematic reduction of the allocation to education every year. Nigeria should take a leaf out of South Africa's book on performance based funding. Salmi and Hauptman's (2006) stated that South Africa is the only Africa Nation which has for a number of years set aside most of its core budget for teaching, research and other services based multiple performance measures.

Poor Government Monitoring: The challenges of funding tertiary institutions in Nigeria is improper monitoring on the part of government either state or federal to monitor funds allocated to execute contracts or purchase instructional materials in tertiary institutions. The political atmosphere in the country does not give room to proper monitoring of funds to execute contract or purchase of educational facilities. The problem of poor government monitoring has affected the development of tertiary institutions in Nigeria, as funds allocated towards development of tertiary institutions never utilized to achieve the goals of education in the country. In the words of Manga (2016) states that mismanagement, deterioration of physical facilities and improper 
award of contracts are the major challenges in Nigerian higher educational institutions. This could be attributed to poor monitoring of activities of authorities of tertiary institutions on the part of government.

Lack of Community Participation: Inability of host communities to support government in funding tertiary institutions poses serious challenges to the development of tertiary institutions in Nigeria. Community members in Nigeria believed that it is sole responsibility of government to finance tertiary education, since those institutions belong to government. Unlike other part of the world, where community contributes certain percentage of funds to assist government since they are the major beneficiaries of these institutions. However, political, economic, religion belief culture and attitude of host communities towards Western education contribute to inadequate funding of tertiary institutions in Nigeria. Host communities show less concerned to the funding of tertiary institutions. It is believed that since governments are the proprietors of these institutions, therefore, they should be responsible for its funding.

Inadequate Private Sector Participation: Inability of private sector to support government in funding education poses serious challenges to the development of tertiary institutions in Nigeria. Private sector is the major employer of products of tertiary institutions and they insignificantly contributed to the development of education in Nigeria. In advanced countries, government partner with private sector to boost the productivity of the tertiary institutions. However, in Africa and Nigeria in particular. It is assumed that funding of education is the sole responsibility of government at all levels. Nigerian government did not create avenue for the private sector to render meaningful financial support to the development of tertiary education.

Over- dependence on Government Funds: Most tertiary institutions in Nigeria are owned and established by the governments state or federal level. The authorities of these tertiary institutions heavily depend on government monthly allocation to carry out their activities in the institutions. However, increase in enrolment rate which resulted to establishment of more tertiary institutions without corresponding increased in funding pose serious challenges to the development of tertiary institutions in Nigeria. The problem of funding is the most persistent and thorny issue militating against the capacity of many institutions to render quality services, as many of the tertiary institutions find it difficult to maintain school their facilities.

\section{Suggestions}

Based on the aforementioned challenges, the paper offers the following suggestions:

Provision of Adequate Funds: Education is an instrument of political, social and economic development of any nation. Therefore, in order to sustained achievements of Sustainable Development Goals (SDGs) through teaching and research, attainment of vision 20:2020 and production of competent manpower there is need for Nigerian government to adequately provide funds to the development of tertiary institutions in Nigeria. There is need for government to implement $26 \%$ benchmark for every developing nation from annual budget to education sector. Adequate provision of fund will enable tertiary institutions offer quality services needed for the development of any nations. 
Proper Monitoring of Funds by the Government: There is need for government at all levels to initiate policy that will guide the award and execution of contracts in tertiary institutions in Nigeria. The implementation of Treasury Single Account (TSA) by the government at all levels will minimize the level of corrupt practice and block financial leakages, mismanagement of funds, prudent spending and effective utilization of educational funds. Adekola (2015) says that implementation of Treasury Single Account (TSA) encourages prudency, transparency, accountability, as well as effective utilization of public funds in Nigeria.

Encouragement of Community Participation: There is the need to encourage, persuade and re-orientate the community that funding of tertiary education is not the sole responsibility of government. Members of the community need to support government financially and through other means to boost the productivity of higher education in Nigeria. Community can assist government in building classrooms, furniture, scholarship to students, school buses etc for effective services delivery. Mahuta (2016) says that host communities especially in the Southern part of the country have been supporting government in funding higher institutions through donation of funds, construction of school buildings, staff offices and so on for effective running of the institutions.

Research and Development: Since higher educational institutions in Nigeria, especially universities were established mainly for teaching and research and development, therefore, there is need for the authorities of these higher educational institutions to established research and development centers virtually in all institutions for scholars to dwell into all kind of researches through which the outcome could be sold to government or private organizations in exchange for money. Clark (2001) suggested that Nigerian tertiary institutions especially universities, should review their curricular on a regular basis in order to ensure that the content of their teaching reflects the rapidly advancing frontiers of human knowledge in all disciplines. Breakthrough in any kind of researches could serve as alter nature source of funding tertiary institutions.

Higher institutions need to explore alternative means of funding and become less dependent on government allocations. Higher institutions need to improve on their internally generated revenue to complement funds from government. Stakeholders in education such as parents, guardians, Non Governmental Organizations (NGOs), International Organizations should support and subsidize the funding of tertiary institutions in Nigeria in the area of programmes, project and provision of service.

\section{Conclusion}

Adequate funding of higher education has become imperative in an attempt to provide quality education to produce competent manpower that can compete globally. To successfully attained the goals of education and vision 2020 if the authorities of higher educational institutions can explore alternative sources of funds such as stakeholders in education, parents, guidance, public private partnership, endowment fund, donations international organizations such as world bank, London club, Paris club, and internal efficiency and less dependent on government allocation. This will 
assist higher institutions in Nigeria to expand their capacities in providing quality education to the people.

\section{References}

Adeniyi, P. O. (2008). Repositioning Nigerian universities for national sustainable development. A Paper Presented at the $10^{\text {th }}$ quarterly public affairs forum series, Ondo State, Nigeria.

Ahmed, S. (2013). Public and private higher education financing in Nigeria. European Scientific Journal. 11(7): 92-109.

Akinsanya, O. O. (2000). Financing Higher Education in Nigeria. International Journal of African American- Studies, 6(1): 87-101.

Akintoye, I. R. (2008). Optimizing output from tertiary educational institutions via adequate funding: A Lesson from Nigeria. International research journal of finance and economics, 1(14): 192.

Bamiro, O. A. \& Adedeji, O. S. (2010). Sustainable financing of higher education in Nigeria. Ibadan: Ibadan University Press.

Britain - Nigeria Educational Trust (2009). Nigeria Digest BritainNigerian@btinternet.com

Christiana, O. O. (2011). Modes of Funding Nigerian Universities and the Implications on performance. Journal of International Education Research, 7(4): 76-82.

Clark, B. (2001). The entrepreneurial University: New foundations for collegiality, autonomy and achievement. Higher Education Management, 13 (2): 9-24.

Ekundayo, T.A. (2008). Expanding access to higher education in Nigeria. The question of Quality Control. Journal of Performing Higher Education in Africa, 3(22): 36-40.

Federal Government of Nigeria (2004). National Policy on Education. NERDC.

Hincliffe, K. (2002). Public expenditure on education in Nigeria. Issues and estimates and some implication Washington D.C. World Bank.

Imhabekhai, C. I. \& Tonwe, D. A. (2001). Funding higher education in Ogun State Nigeria. Evaluation Research, 1(5) 30-37.

Mahuta, G. A. (2017). Advanced educational finance, unpublished manuscript, Usmanu Danfodiyo University, Sokoto.

Manga, S. D. (2016). Advanced economics of education. unpublished manuscript, Usmanu Danfodiyo University, Sokoto. 
Nwosu, E. (2009). ETF and Funding of Tertiary Education in Nigeria. Cdnwosu2@yahoo.com

Obasi, E. (2000). The economics of education in Nigeria. Mbaise, New Vision Publishers.

Ogbodo, C. M. (1995). Financing education in Nigeria. In Peretomode, V. F. (Ed.) Introduction to Educational Administration Planning and Supervision. Lagos: Joja Educational Research and Publishers.

Aina, O. I. (2002). Alternative modes of financing higher education in Nigeria and implication for university governance. Africa Development, XXVII (1\&2): 236-262.

Okebukola, P. (2003). Issues in funding University education in Nigeria. NIK Monograph series. Abuja: National Universities Commission.

Okunamiri, P. O. (2002). Recourses and Guidelines for Educational Financing in Tertiary Institutions. Owerri, Fasmen Educational and Research Publications.

Olagboye, A. A. (2004). Introduction to educational management in Nigeria. Ibadan: Daily graphics (Nigeria Limited).

Olanrewaju, O. (2003). Financing education in Nigeria; what has the education tax fund achieved. In contemporary issues in educational management. A book of hoonour Ibadan, Awemark Industrial Printers (25-36).

Olubiyo, S. O. (2011). An Overview of the Nigerian financial market before and during the Deregulation of the Economy 1995.

Salmi, J. \& Hauptman, A. M. (2006). Resource allocation mechanisms in tertiary education: A typology and an assessment in Global University Network for Innovation (GUNI) (Ed.) higher education in the world 2006. The financing of universities (pp60-83). Basingtoke, UK, Palgove Macmillan.

Udoh, G. (2008). Alternative sources of funding university education in Nigeria. $A n$ Introduction and Multi-Disciplinary Journal, 2 (3): 98-110.

Wrero, E. J. (1996). Towards the Nigerian University's of the $21^{\text {st }}$ Century: challenges and opportunities INT. Imole and I. Nassar (Eds). Nigeria Administration and beyond the year 2000 AD: challenges and opportunities. Lagos: strategic International Press.

Yusuf, L. A. (2010). Resourceful financing management as panacea for university sustainability in a depressed economy. Pakistan Journal of Social Sciences, 7 (5): 347-350. 